\title{
Pilot trial of autologous dendritic cells loaded with tumor lysate(s) from allogeneic tumor cell lines in patients with metastatic medullary thyroid carcinoma
}

\author{
THOMAS BACHLEITNER-HOFMANN ${ }^{1 *}$, JOSEF FRIEDL $^{1 *}$, MICHAELA HASSLER $^{1 *}$, HUBERT HAYDEN $^{1}$, \\ PETER DUBSKY $^{1}$, MONIKA SACHET ${ }^{1}$, ERWIN RIEDER ${ }^{1}$, ROSWITHA PFRAGNER $^{2}$, CHRISTINE BROSTJAN $^{1}$, \\ STEFAN RISS ${ }^{1}$, BRUNO NIEDERLE ${ }^{1}$, MICHAEL GNANT $^{1}$ and ANTON STIFT $^{1}$ \\ ${ }^{1}$ Department of Surgery, Medical University of Vienna, A-1090 Vienna; \\ ${ }^{2}$ Department of Pathophysiology, Medical University of Graz, A-8010 Graz, Austria
}

Received December 29, 2008; Accepted February 24, 2009

DOI: 10.3892/or_00000391

\begin{abstract}
Immunotherapy with autologous dendritic cells (DCs) loaded with tumor lysate(s) from allogeneic tumor cell lines is a novel strategy to induce immune responses in cancer patients. We report on a pilot trial of autologous DCs pulsed with tumor cell lysate derived from allogeneic medullary thyroid carcinoma (MTC) cell lines in patients with metastatic MTC. The purpose of this study was to assess the safety, resulting immune responses and clinical activity of the DCs. DCs were injected into a groin lymph node at 3 -week intervals. Monitoring included serial calcitonin tumor marker measurements, radiological imaging and immunological in vitro tests (T-cell Interferon- $\gamma$ detection assay, T-cell cytotoxicity assay). Ten patients (median age 47 years, range 29-77) were enrolled. DC vaccinations were welltolerated and safe. After a median follow-up of 11 months, (range 7-26), 3 (30\%) of 10 patients had stable disease, while $7(70 \%)$ of the patients progressed during treatment. In 2 patients with stable disease, calcitonin decreased below treatment levels, paralleled by a T-cell-mediated immune response. Notably, treatment with DCs pulsed with a combination of different tumor cell lysates was followed by a calcitonin decrease in 4 patients who had previously experienced a calcitonin increase during monotherapy with DCs pulsed with a single lysate. Allogeneic tumor cell lysate-based DC immunotherapy is well-tolerated and safe. Combined treatment with different tumor cell lysate-pulsed
\end{abstract}

Correspondence to: Dr Thomas Bachleitner-Hofmann, Medical University of Vienna, Department of Surgery, Währinger Gürtel 18-20, A-1090 Vienna, Austria

E-mail: thomas.bachleitner-hofmann@meduniwien.ac.at

*Contributed equally

Key words: medullary thyroid carcinoma, immunotherapy, dendritic cells, allogeneic tumor cell lysate
DCs increases the likelihood of a calcitonin tumor marker response and should therefore be preferred over monotherapy with DCs pulsed with a single lysate.

\section{Introduction}

Medullary thyroid carcinoma (MTC) is a calcitonin-producing tumor of the parafollicular $\mathrm{C}$ cells which accounts for 5-10\% of all thyroid malignancies (1-3). MTC occurs sporadically, in a familial form, or associated with multiple endocrine neoplasia (MEN) type $2 \mathrm{~A}$ or $2 \mathrm{~B}$. It has a slow but progressive clinical course with an early involvement of lymph nodes. Calcitonin is the most specific circulating marker and is widely used for diagnosis and monitoring. The solely curative treatment for MTC is total surgical removal of all neoplastic tissue which requires meticulous surgery. However, effective palliative treatments are lacking once distant metastases have occurred.

We have previously shown that tumor lysate-pulsed dendritic cells (DCs) are suited to stimulate antitumor T-cell responses against autologous MTC cells in vitro (4). DCs can be generated in vitro from peripheral blood mononuclear cells (PBMCs) using GM-CSF and IL-4 (5). These immature DCs can be loaded with tumor lysate and matured by inflammatory stimuli including TNF $\alpha$, IL-1ß or CD40-ligand $(6,7)$. Because of their unique capacity to stimulate T-cells, DCs are a promising option for cancer immunotherapy, including surgically incurable MTC (8-11).

In two clinical trials using autologous tumor lysate-pulsed DCs we observed objective tumor marker responses and/ or disease stabilization in several patients with metastatic MTC (12,13). Encouraging results were also obtained by Schott et al who treated 7 patients and observed clinical and/or tumor marker responses in 3 patients, including a patient with a complete regression of detectable liver metastases and a significant reduction of pulmonary lesions (14).

Immunotherapy with autologous DCs pulsed with tumor cell lysate derived from allogeneic tumor cell lines is a promising novel approach to induce antitumor immune responses in cancer patients (15-19). The use of tumor cell 
Table I. Patient characteristics.

\begin{tabular}{|c|c|c|c|c|c|c|c|c|}
\hline $\begin{array}{l}\text { No. of } \\
\text { patients }\end{array}$ & $\begin{array}{l}\text { Age/ } \\
\text { Sex }\end{array}$ & $\begin{array}{l}\text { Tumor } \\
\text { type }^{\mathrm{a}}\end{array}$ & $\begin{array}{l}\text { Histology } \\
\text { at diagnosis }\end{array}$ & Surgery ${ }^{b}$ & $\begin{array}{l}\text { Previous } \\
\text { treatment }^{\mathrm{c}}\end{array}$ & $\begin{array}{l}\text { Metastatic } \\
\text { disease }^{\mathrm{d}}\end{array}$ & $\begin{array}{l}\text { Study entry } \\
\text { (months } \\
\text { after } \\
\text { diagnosis) }\end{array}$ & $\begin{array}{l}\text { Calcitonin } \\
\text { at study } \\
\text { entry } \\
(\mathrm{pg} / \mathrm{ml})\end{array}$ \\
\hline $1 \mathrm{CM}$ & $40 / \mathrm{M}$ & S & $\mathrm{T} 4, \mathrm{~N} 1$ & TE, ND, MLNE, LB & DCs (auTL) & $\begin{array}{l}\text { Cervical LNs, } \\
\text { lungs, liver }\end{array}$ & 123 & 2568 \\
\hline $2 \mathrm{MS}$ & $55 / \mathrm{F}$ & $S$ & T2a, N1b & TE, ND & $\mathrm{N}$ & Bone & 86 & 6010 \\
\hline $3 \mathrm{FE}$ & $43 / \mathrm{M}$ & MEN-2 & T1b, N1 & TE, ND, MLNE, LB & $\mathrm{N}$ & Liver, bone & 108 & 37044 \\
\hline $4 \mathrm{HS}$ & $77 / \mathrm{M}$ & S & $\mathrm{T} 4 \mathrm{a}, \mathrm{N} 1 \mathrm{~b}$ & TE, ND & $\mathrm{N}$ & Cervical LNs, bone & 61 & 13874 \\
\hline $5 \mathrm{KP}$ & $45 / \mathrm{M}$ & $S$ & $\mathrm{~T} 4, \mathrm{~N} 1 \mathrm{a}$ & TE, ND, MLNE & IFN- $\alpha$, DCs (auTL) & Mediastinal LNs & 148 & 661 \\
\hline $6 \mathrm{JD}$ & $43 / \mathrm{M}$ & $S$ & $\mathrm{~T} 4 \mathrm{~b}, \mathrm{~N} 1 \mathrm{~b}$ & TE, NE, MLNE & $\mathrm{N}$ & $\begin{array}{l}\text { Cervical LNs, } \\
\text { trachea, esophagus }\end{array}$ & 1 & 683 \\
\hline $7 \mathrm{AP}$ & $29 / F$ & S & T4b, N1b & TE, NE, MLNE & DCs (auTL) & Cervical LNs & 31 & 4575 \\
\hline $8 \mathrm{WO}$ & $55 / \mathrm{M}$ & MEN-2 & $\mathrm{T} 4, \mathrm{~N} 1$ & TE, ND & RXT & Lungs, hilar LNs & 25 & 774 \\
\hline $9 \mathrm{JK}$ & 49/M & S & T4, N1 & TE, ND, ALND, LR & $\begin{array}{c}\text { IFN- } \alpha, \text { HT, SS, } \\
\text { MRXT, DCs (auTL) }\end{array}$ & $\begin{array}{l}\text { Axillary LNs, } \\
\text { mediastinal LNs, } \\
\text { lungs, pleura, liver }\end{array}$ & 220 & 34900 \\
\hline $10 \mathrm{ES}$ & $70 / \mathrm{M}$ & $S$ & $\mathrm{~T} 4 \mathrm{~b}, \mathrm{~N} 1$ & TE, ND, PHR, LB & DCs (auTL) & $\begin{array}{l}\text { Cervical LNs, } \\
\text { mediastinal LNs, } \\
\text { liver }\end{array}$ & 1 & 3130 \\
\hline
\end{tabular}

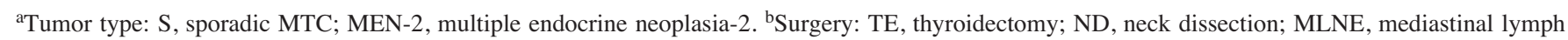
node exstirpation; LB, liver biopsy; ALND, axillary lymph node dissection; LR, liver resection; PHR, pharyngeal resection. ${ }^{\mathrm{c} P r e v i o u s}$ treatment: DCs (auTL), autologous tumor lysate-pulsed DCs; IFN $\alpha$, Interferon-alpha; RXT, radiotherapy; HT, hyperthermia; SS, somatostatin; MRXT, mediastinal radiotherapy. ${ }^{\mathrm{d}}$ Metastatic disease: $\mathrm{LN}$, lymph node.

lines offers the advantage of having unlimited tumor material available for DC pulsing since the cells can be easily passaged in vitro. Also, it offers the possibility to combine tumor cells with different antigenic profiles for therapy. Further support for allogeneic tumor lysate-based DC therapy comes from a phase I study in melanoma patients which suggests that an HLA match between patients and tumor cells is not required for a specific T-cell response (20). Here we report the safety, resulting immune responses and clinical activity of the treatment with autologous monocyte-derived DCs pulsed with allogeneic MTC tumor cell lysate in patients with metastatic MTC.

\section{Patients and methods}

Inclusion criteria. Patients aged 18-75 years with metastatic MTC were included in this trial. Patients were required to have an expected survival of $\geq 3$ months, a Karnofsky index of $\geq 60$ and normal renal, hepatic, and hematopoietic function. No chemotherapy, radiotherapy, or immunotherapy was allowed for at least 3 months before study enrollment. Patients with antibodies against HIV, hepatitis $\mathrm{B}$ or $\mathrm{C}$ virus and patients with autoimmune disease were excluded. All patients gave written informed consent. The protocol was approved by the Institutional Ethics Committee of the University of Vienna.

Patient characteristics. Patient characteristics are shown in Table I. Eight (80\%) of 10 patients had sporadic tumors and $2(20 \%)$ patients had MEN-2 tumors. At initial diagnosis,
$8(80 \%)$ patients presented with a T4 tumor and $10(100 \%)$ patients had positive lymph nodes. The mean interval between diagnosis and study entry was 74 months (range 1-220 months). All patients had calcitonin levels $>500 \mathrm{pg} / \mathrm{ml}$ at the time of study entry. Five patients had previously received immunotherapy with autologous tumor lysate-pulsed DCs.

DC preparation. $\mathrm{CD}_{14}{ }^{+}$cells were purified from $\mathrm{PBMCs}$ using a magnetic bead-conjugated anti-CD14 monoclonal antibody (Miltenyi Biotec, Bergisch Gladbach, Germany). The cells were seeded at $1 \times 10^{6} / \mathrm{ml}$ in RPMI-1640, supplemented with $1000 \mathrm{U} / \mathrm{ml}$ GM-CSF (Berlex Laboratories, Richmond, CA), 500 U/ml IL-4 (Strathmann PBH, Hamburg, Germany), $10 \%$ heat-inactivated fetal bovine serum (FBS, HyClone, Perbio, Logan, UT) and $50 \mu \mathrm{g} / \mathrm{ml}$ gentamycin (Gibco-BRL) in a $5 \% \mathrm{CO}_{2}$ humidified atmosphere at $37^{\circ} \mathrm{C}$. On day 5 , DCs were pulsed with $200 \mu \mathrm{g} / \mathrm{ml}$ of tumor cell lysate for $12 \mathrm{~h}$. They were then matured with $1 \mu \mathrm{g} / \mathrm{ml} \mathrm{TNF} \alpha$ (provided by H.R. Alexander Jr from the National Cancer Institute, MD) and $1000 \mathrm{U} / \mathrm{ml} \mathrm{IFN}-\gamma$ (Boehringer Ingelheim, Vienna, Austria) for $12 \mathrm{~h}$, followed by $50 \mathrm{ng} / \mathrm{ml}$ LPS for $4 \mathrm{~h}$. Flow cytometric analysis of the DCs was performed before every vaccination and showed mature DCs positive for CD1a, CD40, CD80, CD 83 and CD86. For vaccine preparation, the cells were washed and dissolved in $300 \mu 1$ phosphate-buffered saline (PBS, Gibco-BRL). DC vaccinations were administered 3 -weekly on an outpatient basis. The cell suspension was injected into the patient's groin lymph node under ultrasound guidance. 
Table II. Treatment modalities and clinical responses to treatment.

\begin{tabular}{|c|c|c|c|c|c|c|c|c|}
\hline \multirow{2}{*}{$\begin{array}{l}\text { No. of } \\
\text { patients }\end{array}$} & \multirow{2}{*}{$\begin{array}{c}\text { Total no. of } \\
\text { vaccinations } \\
\text { (cycle } 1 / 2)\end{array}$} & \multicolumn{2}{|c|}{ Cell lines used for DC pulsing } & \multirow[b]{2}{*}{ FU months } & \multirow[b]{2}{*}{ Toxicity } & \multicolumn{2}{|c|}{ Response $^{a}$} & \multirow[b]{2}{*}{ Disease status ${ }^{\mathrm{b}}$} \\
\hline & & Cycle 1 & Cycle 2 & & & Calcitonin & Imaging & \\
\hline $1 \mathrm{CM}$ & $31(15 / 16)$ & GSJO & GSJO, SHER-I & 21 & $\mathrm{~N}$ & $-41 \%$ & SD & AWD \\
\hline $2 \mathrm{MS}$ & 16 & GSJO, SHER-I & - & 8 & $\mathrm{~N}$ & $-17 \%$ & SD & AWD \\
\hline $3 \mathrm{FE}$ & 23 & GSJO, SHER-I & - & 13 & $\mathrm{~N}$ & $+3 \%$ & SD & AWD \\
\hline $4 \mathrm{HS}$ & 16 & GSJO, SHER-I & - & 10 & $\mathrm{~N}$ & $+82 \%$ & PD & AWD \\
\hline $5 \mathrm{KP}$ & $37(21 / 16)$ & GSJO & GSJO, SHER-I & 20 & $\mathrm{~N}$ & $+59 \%$ & PD & AWD \\
\hline $6 \mathrm{JD}$ & 16 & GSJO, SHER-I & - & 8 & $\mathrm{~N}$ & $+54 \%$ & PD & AWD \\
\hline $7 \mathrm{AP}$ & $38(17 / 21)$ & GSJO & GSJO, SHER-I & 26 & $\mathrm{~N}$ & $+34 \%$ & PD & AWD \\
\hline $8 \mathrm{WO}$ & 15 & GSJO, SHER-I & - & 8 & $\mathrm{~N}$ & $+229 \%$ & PD & AWD \\
\hline $9 \mathrm{JK}$ & $30(19 / 11)$ & GSJO & GSJO, KJOS-II & 20 & $\mathrm{~N}$ & $+316 \%$ & PD & DOD \\
\hline $10 \mathrm{ES}$ & 11 & GSJO & - & 7 & $\mathrm{~N}$ & $+150 \%$ & PD & AWD \\
\hline
\end{tabular}

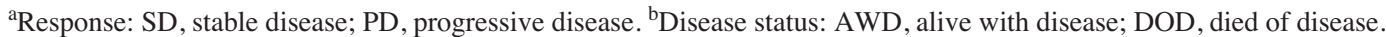

Tumor cells. MTC tumor cell lines (GSJO, KJOS-II, SHER-I) were obtained from patients with MTC as previously described $(21,22)$. GSJO cells were derived from the primary tumor of a patient with hereditary MTC. SHER-I and KJOS-II cells were obtained from 2 patients with sporadic MTC participating in this study: SHER-I tumor cells were derived from the primary tumor of patient 4, and KJOS-II tumor cells were derived from an axillary metastasis of patient 9 . Tumor cells were cultured in DMEM F12 + 10\% FBS and $50 \mu \mathrm{g} / \mathrm{ml}$ gentamycin. All cell lines tested negative for human pathogenic viruses.

Preparation of tumor cell lysate. Tumor cells $\left(1-2 \times 10^{7}\right)$ were washed in PBS, dissolved in sterile water and subjected to 5 freeze/thaw cycles. After centrifugation, the protein content was determined in the supernatant (Pierce Coomassie Plus Protein Assay, Rockford, IL) and aliquots were stored at $-80^{\circ} \mathrm{C}$.

Clinical monitoring. Adverse events were graded according to the World Health Organization (WHO) toxicity criteria. All patients underwent assessment of tumor status at baseline and every 6 months thereafter using ultrasound, computed tomography scan, magnetic resonance imaging and/or PET scan. In all patients, calcitonin was measured at the beginning of the study and monthly thereafter. Clinical response was defined according to the WHO response criteria. Calcitonin tumor marker responses were defined as described previously (14).

Autoantibodies (antinuclear, antihistone, anti-ds-DNA, anti-Ro/SSA, anti-La/SSB, anti-U1-RNA, anti-sm, anti-thyreoglobulin, anti-neutrophil cytoplasmic, anti-thyroid, antismooth muscle, anti-parietal cell, anti-mitochondrial, antiinsulin, anti-pancreatic islet and rheumatoid factors) were analyzed before and at least two times during the vaccination period.

In vitro cytotoxicity assays. T-cells obtained at different timepoints were cocultured with mature tumor lysate-pulsed
DCs at a T:DC ratio of 5:1 in RPMI-1640 + 10\% FBS without cytokines. On day 5, the T-cells were harvested and T-cellmediated cytotoxicity against MTC tumor cells was measured using a standard in vitro 4-h europium release assay as described previously (4).

Intracytoplasmic interferon gamma (IFN- $\gamma)$ detection assays. Intracellular staining for IFN- $\gamma$ expression by peripheral blood $\mathrm{T}$-cells was performed as described previously $(12,13)$. Briefly, $5 \times 10^{6} \mathrm{~T}$-cells were cocultured with $1 \times 10^{6}$ mature tumor lysate-pulsed DCs for $18 \mathrm{~h}$ without addition of cytokines. Ten $\mu \mathrm{mol} / \mathrm{l}$ Monensin (Sigma, Vienna, Austria) were added during the last $5 \mathrm{~h}$ to block protein secretion. After harvesting, the cells were washed and permeabilized using a commercially available kit (Immunotech, Marseille, France) and stained with a PE-labeled anti-IFN- $\gamma$ and a FITC-labeled anti-CD3 antibody (Immunotech). Samples were analyzed on an EPICS XL flow cytometer (Beckman Coulter, Fullerton, CA).

\section{Results}

Treatment modalities. Treatment modalities are specified in Table II. All patients received autologous DCs pulsed with tumor lysate derived from GSJO cells. Patients 1-9 also received autologous DCs pulsed with a second tumor lysate (SHER-I or KJOS-II) later during treatment. Six (60\%) of 10 patients received one treatment cycle and 4 (40\%) patients received 2 treatment cycles. Both treatment cycles consisted of a median of 16 vaccinations [range 11-23 (cycle 1) and 11-21 (cycle 2)].

Clinical responses to treatment. DC vaccinations were well tolerated. No grade 3 or 4 toxicities or autoimmune reactions were observed. Table II shows the calcitonin tumor marker and radiological responses during the study. In patients 1 and 2 , calcitonin decreased below pretreatment levels ( -41 and $-17 \%$, respectively). In patient 3 , calcitonin remained stable over 13 months $(+3 \%)$. In the remaining patients, calcitonin 

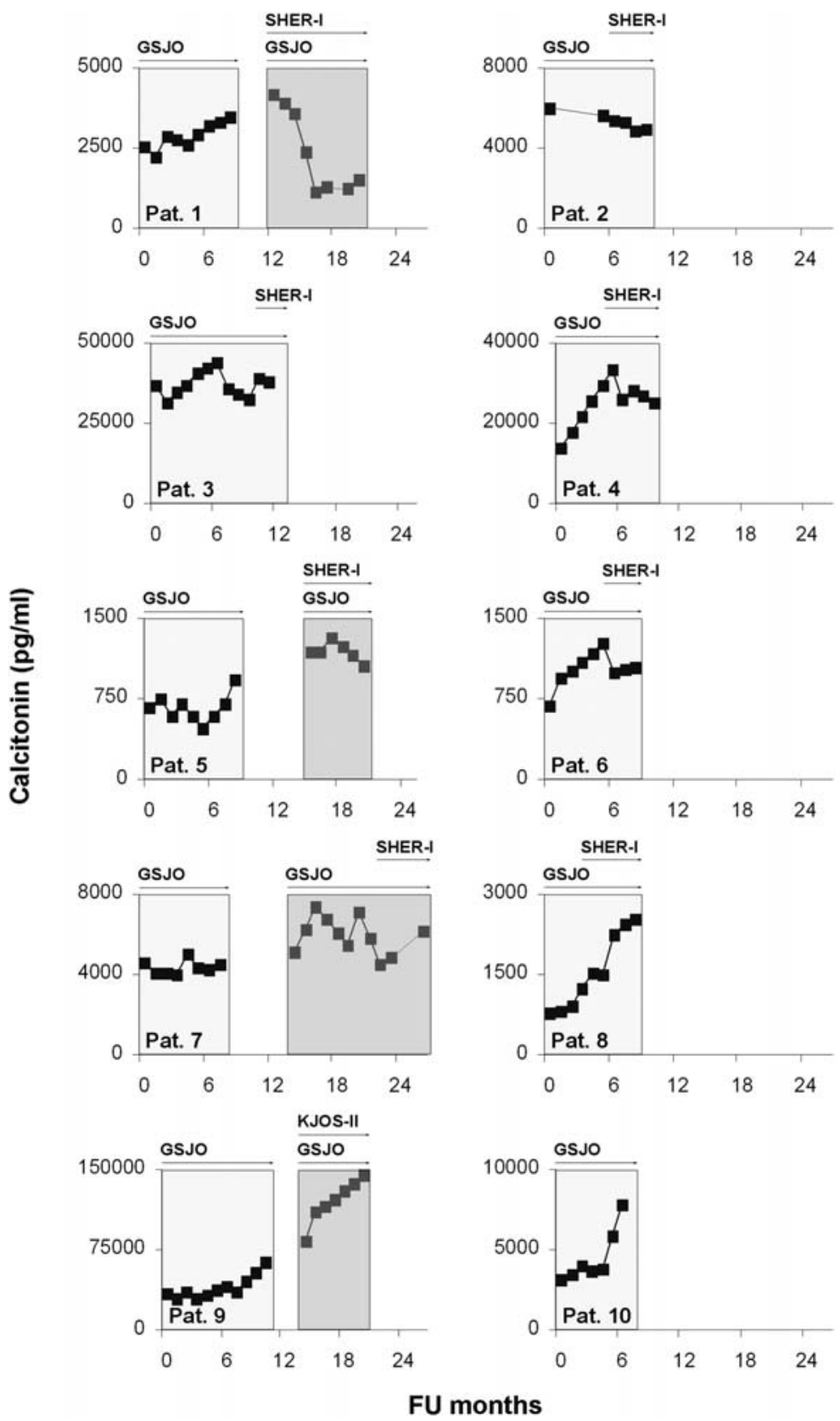

Figure 1. Calcitonin levels in patients treated with allogeneic tumor lysate-pulsed DCs. Tumor cell lines used for DC pulsing and periods of combined treatment with different tumor lysate-pulsed DCs are shown at top of each panel.

increased, with a more than 2 -fold calcitonin increase in patients 8-10. Correlating with the calcitonin changes during therapy, radiological imaging showed disease stabilization in patients 1,2 and 3, including an objective regression of metastatic lesions in the liver and cervical lymph nodes in patient 1 which did not meet the criteria for a partial response. After a median follow-up of 11 months (range 7-26 months), $9(90 \%)$ patients remain alive with disease whereas patient 9 died 20 months after study entry from rapidly progressive metastatic disease to the liver and lungs.

Efficacy of combined treatment with different tumor lysatepulsed DCs. Fig. 1 illustrates calcitonin levels, tumor lysates used for DC pulsing and periods of combined treatment with different tumor lysate-pulsed DCs. In the majority of patients, calcitonin levels increased during monotherapy with GSJO- pulsed DCs, indicating poor immunological activity of DCs pulsed with this tumor lysate. We therefore introduced DCs pulsed with a second tumor lysate in patients 1-9, hypothesizing that a broader spectrum of tumor antigens for DC pulsing would increase the likelihood of an antitumor immune response. The second tumor lysate was derived from SHER-I tumor cells (patients 1-8) or KJOS-II tumor cells (patient 9). Table III lists the HLA type of patients and tumor cell lines. Noticeably, introduction of SHER-I-pulsed DCs was followed by a $>70 \%$ calcitonin decrease $(4190 \mathrm{pg} / \mathrm{ml}$ to $1160 \mathrm{pg} / \mathrm{ml})$ in patient 1 . Drops of calcitonin levels following introduction of SHER-I-pulsed DCs were also seen in patients 4 (calcitonin change: $-25 \%), 5(-20 \%)$ and $6(-18 \%)$, all of whom had previously experienced increasing calcitonin levels during monotherapy with GSJO-pulsed DCs. In patient 2 where calcitonin had decreased moderately during monotherapy 
Table III. HLA type of patients and tumor cell lines.

\begin{tabular}{|c|c|c|c|c|c|}
\hline \multirow[b]{2}{*}{ No. of patients } & \multicolumn{5}{|c|}{ HLA type } \\
\hline & A & B & $\mathrm{C}$ & DR & DQ \\
\hline $1 \mathrm{CM}$ & 24 (9), 29 (19) & $5,44(12)$ & & & \\
\hline $2 \mathrm{MS}$ & 1,68 & 7,40 & w7, w15 & 15 & 6 \\
\hline $3 \mathrm{FE}$ & $24(9), 31(19)$ & 27,57 (17) & w1, w6 & $8,11(5)$ & \\
\hline $4 \mathrm{HS}$ & 1,3 & 8,15 & w3, w7 & 3,4 & 2,3 \\
\hline $5 \mathrm{KP}$ & 2,24 & 49,55 & w3, w7 & 11,13 & 3,6 \\
\hline $6 \mathrm{JD}$ & 2,8 & 8,18 & w7, w15 & 8,10 & \\
\hline $7 \mathrm{AP}$ & $2,30(19)$ & 18,37 & w5, w6 & 1,3 & \\
\hline $8 \mathrm{WO}$ & $2,24(9)$ & $39(16), 60(40)$ & w3, w7 & & \\
\hline $9 \mathrm{JK}$ & $24(9)$ & 15,27 & w1, w2 & 1,3 & 2,5 \\
\hline $10 \mathrm{ES}$ & 1,3 & $8,44(12)$ & w5, w7 & 3,4 & \\
\hline \multicolumn{6}{|l|}{ Cell lines } \\
\hline GSJO & 1,3 & 8,35 & w4, w7 & 1,3 & 2,5 \\
\hline KJOS-II & $24(9)$ & 15,27 & w1, w2 & 1,3 & 2,5 \\
\hline SHER-I & 1,3 & 8,15 & w3, w7 & 3,4 & 2,3 \\
\hline
\end{tabular}

Target: GSJO

SHER-I

Pat. 1
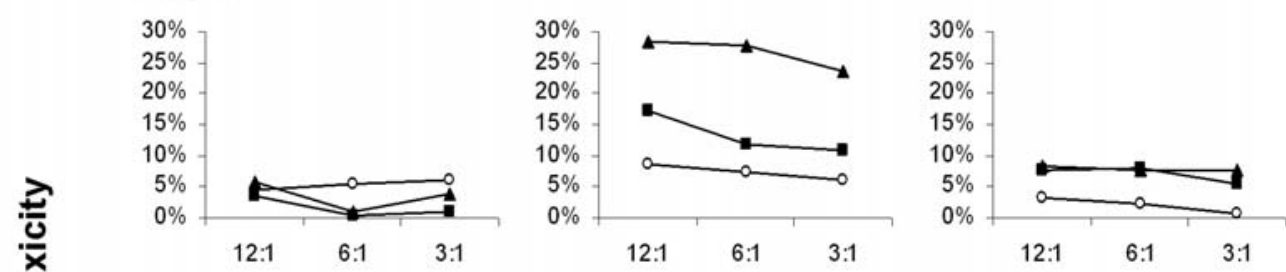

\section{Pat. 2}
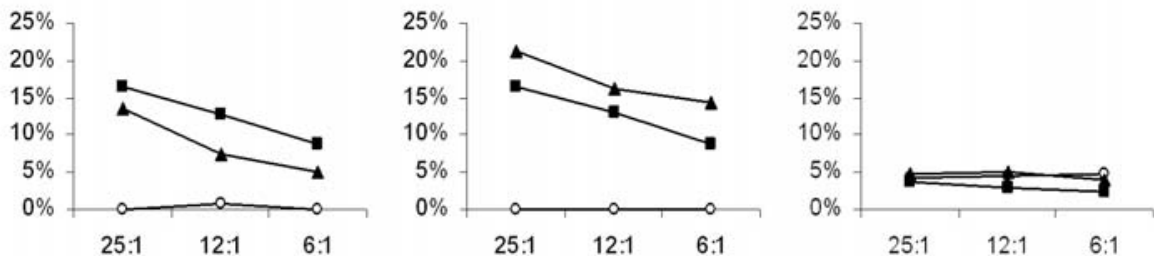

Effector : Target ratio

Figure 2. Cytotoxic T-cell responses. After stimulation with allogeneic MTC tumor lysate-pulsed DCs, T-cells were tested against the respective MTC tumor cell lines in vitro. For control, T-cells were also tested against unrelated PANC-1 pancreatic carcinoma cells. The respective target cell lines are indicated at the top of the panels. Filled squares, T-cells stimulated with GSJO-pulsed DCs; filled triangles, T-cells stimulated with SHER-I-pulsed DCs; open circles, unstimulated T-cells.

with GSJO-pulsed DCs, introduction of SHER-I-pulsed DCs was associated with a further calcitonin decrease. No effect of combined treatment with SHER-I-pulsed DCs was observed in patient 3 (no calcitonin change), as well as in patients 7 and 8 (calcitonin increase). Also, combined treatment with KJOS-II-pulsed DCs did not prevent the rapid increase of calcitonin levels in patient 9.
Cytotoxic T-cell responses. To evaluate the immunostimulatory capacity of the DCs, we next assessed their ability to induce cytotoxic T-cell responses against the MTC tumor cells used for DC pulsing in vitro. For control, we tested T-cells stimulated with MTC tumor lysate-pulsed DCs against unrelated allogeneic PANC-1 pancreatic carcinoma cells. Fig. 2 illustrates the results of the T-cell cytotoxicity 


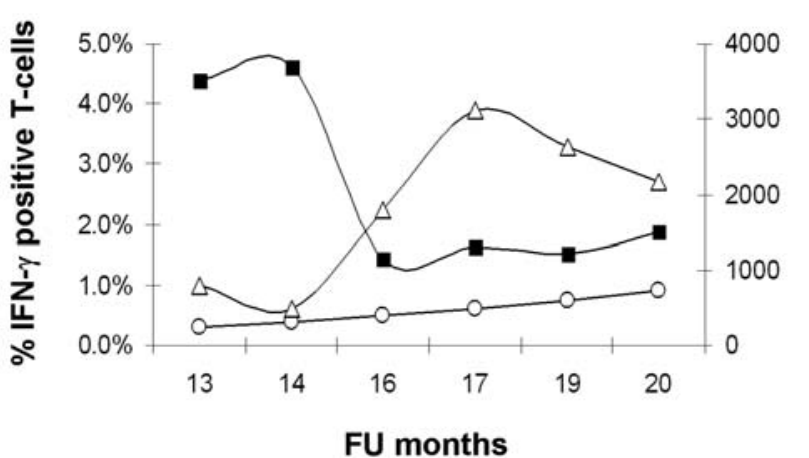

Figure 3. IFN- $\gamma$-positive T-cells and calcitonin levels in patient 1 . T-cells from patient 1 obtained at different time-points were stimulated with SHER-I-pulsed DCs, analyzed for their expression of IFN- $\gamma$ and correlated with calcitonin tumor marker levels. Open triangles, T-cells stimulated with SHER-I-pulsed DCs; open circles, unstimulated T-cells; filled squares, calcitonin levels

assays for patients 1 and 2 where calcitonin levels dropped below pretreatment levels, suggestive of an immunological response: in patient 1, SHER-I-pulsed DCs elicited a strong cytotoxic T-cell response against SHER-I tumor cells, correlating with the marked decline of calcitonin levels after SHER-I-pulsed DCs had been introduced. In contrast, no T-cell-mediated cytotoxicity against GSJO tumor cells was observed, reflecting the lack of clinical efficacy of GSJOpulsed DCs in this patient. In patient 2, cytotoxic T-cell responses against both GSJO and SHER-I tumor cells were observed, suggesting that immunoreactivity against tumor antigens from both tumor cell lines contributed to the decreasing calcitonin levels in this patient. In neither of the patients did MTC tumor lysate-pulsed DCs elicite a cytotoxic T-cell response against unrelated PANC-1 tumor cells.

Intracytoplasmic IFN- $\gamma$ detection assays. To further characterize the immunological responses during treatment with MTC tumor lysate-pulsed DCs, serial intracytoplasmic IFN- $\gamma$ detection assays were performed and correlated with calcitonin tumor marker levels. Fig. 3 illustrates the results of the intracytoplasmic IFN- $\gamma$ detection assays performed in patient 1 where a decline of calcitonin tumor marker levels after introduction of SHER-I-pulsed DCs suggested an immunological response to DCs pulsed with this lysate; importantly, the decrease of calcitonin levels after 14 months of follow-up was paralleled by a 6.5-fold increase of SHER-Iimmunoreactive IFN- $\gamma$-positive T-cells between 14 and 17 months. Together with the data obtained in the T-cell cytotoxicity assays this further suggests that an antitumor T-cell response elicited by SHER-I-pulsed DCs contributed to the calcitonin tumor marker response in patient 1 .

\section{Discussion}

We report the results of a pilot trial of autologous DCs pulsed with tumor lysate derived from allogeneic MTC tumor cells in patients with metastatic MTC. Treatment was well-tolerated and safe, and no autoimmune responses were observed. After a median follow-up of 11 months (range 7-26 months), 3
(30\%) of 10 patients had stable disease, while 7 (70\%) of the patients progressed during DC immunotherapy.

Recently, it has been shown that autologous DCs loaded with allogeneic tumor cell lysate are a promising novel approach to induce antitumor T-cell responses in cancer patients (15-20). Loading DCs with allogeneic tumor cell lysate offers several advantages compared with autologous tumor lysate: first, no surgery is required to obtain tumor tissue for lysate preparation. Second, tumor cell lines are an unlimited source of tumor material since the cells can be easily passaged in vitro. Third, treatment is possible even for patients in whom autologous tumor material is no longer available, for patients whose metastatic lesions are not accessible to surgical removal, or for patients with unknown metastatic sites. Also, given an array of several tumor cell lines with different antigenic profiles, it is possible to deliver a broad spectrum of different tumor antigens to the DCs, thereby increasing the versatility of the DC vaccine to induce antitumor $\mathrm{T}$-cell responses in individual patients.

In an ongoing collaborative effort we have established several MTC cell lines from various MTC tissue samples (21-24). The cell lines retain their neuroendocrine phenotype and display the biological features of neuroendocrine tumor cells at the molecular level. Considering the extremely small number of MTC cell lines currently available, these cells represent a unique tumor bank which can be used as a source of tumor antigens for DC immunotherapy in patients with MTC.

The primary aim of this trial was to assess the feasibility of allogeneic tumor lysate-based DC immunotherapy in patients with MTC. Treatment was well tolerated without side effects and could be performed on an outpatient basis. In none of the patients, evidence for the development of autoimmune disease was found.

The secondary aim was to assess the clinical efficacy of the DC vaccinations and to correlate the clinical responses to treatment with immunological assays in vitro. In our heavily metastasized patient cohort, stable disease was observed in three patients (patients 1-3). In two of these patients (patients 1 and 2), calcitonin decreased below pretreatment levels. For both patients, in vitro T-cell responses were observed: in patient 1 , T-cell cytotoxicity assays showed a cytotoxic T-cell response against SHER-I tumor cells, and serial intracytoplasmic IFN- $\gamma$ detection assays revealed that a sharp decline of calcitonin levels after introduction of SHER-Ipulsed DCs was paralleled by a 6.5-fold increase of SHER-Iimmunoreactive IFN- $\gamma$-positive T-cells. In patient 2 , cytocorrelated with decreasing calcitonin levels during DC immunotherapy. In neither of the patients was a cytotoxic Tcell response against unrelated PANC-1 pancreatic cancer cells observed. This suggests that antitumor immune responses elicited by the DC vaccinations contributed to the calcitonin tumor marker decreases in responders to therapy.

We also compared combined treatment with different tumor lysate-pulsed DCs with the efficacy of single lysatebased DC therapy. Noticeably, calcitonin levels of patient 1 increased during monotherapy with GSJO-pulsed DCs but dropped by $>70 \%$ after combination therapy with SHER-Ipulsed DCs was initiated. Decreases in calcitonin levels after onset of combined treatment with SHER-I-pulsed DCs were 
also observed in patients 4-6, all of whom had experienced rising calcitonin levels during monotherapy with GSJOpulsed DCs. This suggests that combining different tumor lysate-pulsed DCs into one vaccine increases the likelihood of inducing a calcitonin tumor marker response, conceivably due to delivery of a broader spectrum of tumor antigens to be recognized by patient T-cells.

Interestingly, an HLA match between patients and tumor cell lines was not required for inducing an antitumor T-cell response. This is in accordance with findings by Palucka et al who treated melanoma patients with DCs loaded with allogeneic melanoma cells and observed that CD8 ${ }^{+} \mathrm{T}$-cell responses against an HLA-A0201 binding immunodominant MART-1 peptide could also be induced in HLA-A0201negative patients. The authors were able to demonstrate that tumor-associated peptides may bind to several HLA molecules, enabling them to induce T-cell reactivity even in patients with a different HLA subtype (20), a crucial prerequisite for immunotherapy with allogeneic tumor lysate-pulsed DCs.

Owing to a limited number of patients in our trial, conclusions regarding treatment efficacy of allogeneic tumor lysate-based DC immunotherapy in patients with MTC have to be drawn with caution. Disease stabilization together with calcitonin and immunological responses in selected patients are encouraging evidence for clinical and immunological activity of the DCs. However, the majority of patients progressed during treatment, calling for optimization of the DC vaccine to improve the overall efficacy of allogeneic tumor lysate-based DC immunotherapy. Identifying tumor cell combinations with increased immunogenicity for DC pulsing as well as introducing methods that enhance the intrinsic immunostimulatory capacity of the DCs [e.g. heat shock of the DCs (25) or replacing FBS by tumor lysate as protein supplementation during DC culture (26)] are promising strategies in this regard, which we are currently testing in a follow-up clinical trial.

In conclusion, our study shows that immunotherapy with autologous DCs pulsed with allogeneic tumor cell lysate is a safe and well-tolerated novel treatment for patients with metastatic MTC. Combined treatment with different tumor lysate-pulsed DCs seems to enhance the likelihood of inducing an antitumor T-cell response and should therefore be preferred over treatment with DCs pulsed with a single lysate. A followup trial using combined treatment with different allogeneic tumor lysate-pulsed DCs that have been heat shocked for enhanced intrinsic immunogenicity is currently underway at our institution.

\section{Acknowledgments}

This work was supported in part by the Funds for Innovative Interdisciplinary Cancer Research of the City of Vienna and by a research grant from the Dr. Karl Fellinger Foundation for Cancer Research. This work was performed under the auspices of the Center of Excellence for Clinical and Experimental Oncology of the Medical University of Vienna. We thank all our patients for participating in the study. We also wish to thank all nurses and staff surgeons of the Department of Surgery, Medical University of Vienna, for their continuous support.

\section{References}

1. Giuffrida D and Gharib H: Current diagnosis and management of medullary thyroid carcinoma. Ann Oncol 9: 695-701, 1998.

2. Marsh DJ, Learoyd DL and Robinson BG: Medullary thyroid carcinoma: recent advances and management update. Thyroid 5: 407-424, 1995.

3. Vitale G, Caraglia M, Ciccarelli A, Lupoli G, Abbruzzese A, Tagliaferri P and Lupoli G: Current approaches and perspectives in the therapy of medullary thyroid carcinoma. Cancer 91: 1797-1808, 2001.

4. Bachleitner-Hofmann T, Stift A, Friedl J, Pfragner R, Radelbauer K, Dubsky P, Schuller G, Benko T, Niederle B, Brostjan C, Jakesz R and Gnant M: Stimulation of autologous antitumor T-cell responses against medullary thyroid carcinoma using tumor lysate-pulsed dendritic cells. J Clin Endocrinol Metab 87: 1098-1104, 2002.

5. Thurner B, Roder C, Dieckmann D, Heuer M, Kruse M, Glaser A, Keikavoussi P, Kampgen E, Bender A and Schuler G: Generation of large numbers of fully mature and stable dendritic cells from leukapheresis products for clinical application. J Immunol Methods 223: 1-15, 1999.

6. Banchereau J and Steinman RM: Dendritic cells and the control of immunity. Nature 392: 245-252, 1998.

7. Steinman RM: The dendritic cell system and its role in immunogenicity. Annu Rev Immunol 9: 271-296, 1991.

8. Banchereau J and Palucka AK: Dendritic cells as therapeutic vaccines against cancer. Nat Rev Immunol 5: 296-306, 2005.

9. Nestle FO, Alijagic S, Gilliet M, Sun Y, Grabbe S, Dummer R, Burg G and Schadendorf D: Vaccination of melanoma patients with peptide- or tumor lysate-pulsed dendritic cells. Nat Med 4: 328-332, 1998.

10. Schott M, Scherbaum WA and Seissler J: Dendritic cell-based immunotherapy in thyroid malignancies. Curr Drug Targets Immune Endocr Metabol Disord 4: 245-251, 2004.

11. Schott M and Seissler J: Dendritic cell vaccination: new hope for the treatment of metastasized endocrine malignancies. Trends Endocrinol Metab 14: 156-162, 2003.

12. Stift A, Friedl J, Dubsky P, Bachleitner-Hofmann T, Schueller G, Zontsich T, Benkoe T, Radelbauer K, Brostjan C, Jakesz R and Gnant M: Dendritic cell-based vaccination in solid cancer. J Clin Oncol 21: 135-142, 2003.

13. Stift A, Sachet M, Yaghubian R, Bittermann C, Dubsky P, Brostjan C, Pfragner R, Niederle B, Jakesz R, Gnant M and Friedl J: Dendritic cell vaccination in medullary thyroid carcinoma. Clin Cancer Res 10: 2944-2953, 2004.

14. Schott M, Seissler J, Lettmann M, Fouxon V, Scherbaum WA and Feldkamp J: Immunotherapy for medullary thyroid carcinoma by dendritic cell vaccination. J Clin Endocrinol Metab 86: 4965-4969, 2001.

15. Berard F, Blanco P, Davoust J, Neidhart-Berard EM, NouriShirazi M, Taquet N, Rimoldi D, Cerottini JC, Banchereau J and Palucka AK: Cross-priming of naive CD8 T cells against melanoma antigens using dendritic cells loaded with killed allogeneic melanoma cells. J Exp Med 192: 1535-1544, 2000.

16. Pandha HS, John RJ, Hutchinson J, James N, Whelan M, Corbishley C and Dalgleish AG: Dendritic cell immunotherapy for urological cancers using cryopreserved allogeneic tumour lysate- pulsed cells: a phase I/II study. BJU Int 94: 412-418, 2004.

17. Saito H, Dubsky P, Dantin C, Finn OJ, Banchereau J and Palucka AK: Cross-priming of cyclin B1, MUC-1 and survivinspecific $\mathrm{CD}^{+} \mathrm{T}$ cells by dendritic cells loaded with killed allogeneic breast cancer cells. Breast Cancer Res 8: R65, 2006.

18. Salcedo M, Bercovici N, Taylor R, Vereecken P, Massicard S, Duriau D, Vernel-Pauillac F, Boyer A, Baron-Bodo V, Mallard E, Bartholeyns J, Goxe B, Latour N, Leroy S, Prigent D, Martiat P, Sales F, Laporte M, Bruyns C, Romet-Lemonne JL, Abastado JP, Lehmann $\mathrm{F}$ and Velu T: Vaccination of melanoma patients using dendritic cells loaded with an allogeneic tumor cell lysate. Cancer Immunol Immunother 55: 819-829, 2006.

19. Stift A, Friedl J, Dubsky P, Bachleitner-Hofmann T, Benkoe T, Brostjan C, Jakesz R and Gnant M: In vivo induction of dendritic cell-mediated cytotoxicity against allogeneic pancreatic carcinoma cells. Int J Oncol 22: 651-656, 2003.

20. Palucka AK, Ueno H, Connolly J, Kerneis-Norvell F, Blanck JP, Johnston DA, Fay J and Banchereau J: Dendritic cells loaded with killed allogeneic melanoma cells can induce objective clinical responses and MART-1 specific CD $8^{+}$T-cell immunity. J Immunother 29: 545-557, 2006. 
21. Pfragner R, Hofler H, Behmel A, Ingolic E and Walser V: Establishment and characterization of continuous cell line MTC-SK derived from a human medullary thyroid carcinoma. Cancer Res 50: 4160-4166, 1990.

22. Pfragner R, Skofitsch G, Hoger H, Jech M, Rinner B, Siegl V Niederle B, Gnant M, Friedl J and Stift A: Medullary thyroid carcinoma: autologous tumor cell lines for dendritic cell vaccination. Anticancer Res 25: 4225-4230, 2005.

23. Pfragner R, Wirnsberger G, Behmel A, Niederle B, Langle F, Roka R, Mandl A, Purstner P, Auner J and Tatzber F: Biologic and cytogenetic characterization of three human medullary thyroid carcinomas in culture. Henry Ford Hosp Med J 40: 299-302, 1992.

24. Pfragner R, Wirnsberger GH, Ingolic E and Niederle B: Medullary thyroid carcinomas in cell culture-models for future therapies. Wien Klin Wochenschr 114: 279-283, 2002.
25. Bachleitner-Hofmann T, Strohschneider M, Krieger P, Sachet M, Dubsky P, Hayden H, Schoppmann SF, Pfragner R, Gnant M, Friedl J and Stift A: Heat shock treatment of tumor lysate-pulsed dendritic cells enhances their capacity to elicit antitumor $\mathrm{T}$ cell responses against medullary thyroid carcinoma. J Clin Endocrinol Metab 91: 4571-4577, 2006.

26. Dubsky P, Hayden H, Sachet M, Bachleitner-Hofmann T, Hassler M, Pfragner R, Gnant M, Stift A and Friedl J: Allogeneic tumor lysate can serve as both antigen source and protein supplementation for dendritic cell culture. Cancer Immunol Immunother 57: 859-870, 2007. 